\title{
ASUHAN KEPERAWATAN PADA PASIEN GASTRITIS DENGAN PEMBERIAN JUS BUAH PEPAYA UNTUK MENURUNKAN SKALA NYERI DIWILAYAH SEI PANAS KOTA BATAM
}

\author{
${ }^{1}$ Resi Novia \\ ${ }^{2}$ Zaharatul Amaliah \\ Institut Kesehatan Mitra Bunda Batam \\ Email: reno_sivia@yahoo.co.id
}

\begin{abstract}
ABSTRAK
Penyakit Gastritis merupakan salah satu penyakit dalam sepuluh penyakit terbanyak di Kota Batam dan lebih banyak diderita oleh laki - laki dari pada perempuan. Penelitian ini bertujuan untuk melakukan asuhan keperawatan pada pasien gastritis dengan pemberian jus buah pepaya untuk menurunkan intensitas nyeri di wilayah Sei Panas Kota Batam. Metode yang digunakan adalah studi kasus yang dilakukan berdasarkan tahap-tahap asuhan keperawatan meliputi pengkajian, diagnosa, intervensi, implementasi, dan evaluasi keperawatan. Hasil penelitian didapatkan terjadinya penurunan Tingkat nyeri dari skala 5 menjadi skala 0 setelah dilakukan tindakan keperawatan non farmakologi yaitu pemberian jus buah pepaya selama 5 hari berturut-turut. Dapat disimpulkan bahwa jus buah pepaya dapat menurunkan skala nyeri pada pasien gastritis.
\end{abstract}

Kata kunci : Gatritis ; Asuhan Keperawatan ; Jus buah pepaya ; Skala Nyeri

\begin{abstract}
Gastritis is one of the diseases in the top ten diseases in Batam City and affects more men than women. This study aims to provide nursing care to gastritis patients by giving papaya fruit juice to reduce pain intensity in the Sei Panas area of Batam City. The method used is a case study based on the stages of nursing care including assessment, diagnosis, intervention, implementation and evaluation of nursing. The results showed that the pain level decreased from a scale of 5 to a scale of 1 after non-pharmacological nursing action was carried out, namely the provision of papaya fruit juice for 5 consecutive days. The advice given is that it is hoped that health workers can improve nursing care optimally and be able to apply non-pharmacological techniques by providing papaya fruit juice to reduce pain scales.
\end{abstract}

Keywords: Gastritis ; Nursing Care ; Papaya Juice

\section{PENDAHULUAN}

Pada zaman modern saat ini, semakin banyak penyakit yang timbul akibat gaya hidup manusia dan penularan bakteri. Salah satu penyakit akibat gaya hidup manusia dan penularan bakteri adalah penyakit gastritis, yang terjadi karena inflamasi yang terjadi pada lapisan lambung yang menjadikan penderita gastritis merasa nyeri pada bagian perut dan ulu hati. Penyakit ini tidak bisa menular tapi biasanya bakteri Helycobacter pylori masuk ke dalam tubuh manusia melalui makanan (Budiyanto, 2016). 
Gastritis merupakan penyakit yang dapat menyerang seluruh masyarakat dari semua tingkat usia maupun jenis kelamin, namun paling sering gastritis menyerang pada usia produktif. Pada usia produktif masyarakat rentan terkena gastritis karena tingkat kesibukan serta gaya hidup yang diperhatikan serta stres yang mudah terjadi akibat pengaruh faktor-faktor lingkungan. Namun sampai saat ini masih banyak masyarakat yang beranggapan bahwa gastritis timbul karena telat makan (Indayani, 2018). Gastritis biasanya diawali dengan pola makan yang tidak baik dan tidak teratur sehingga lambung menjadi sensitif di saat asam lambung meningkat (Tussakinah \& Burhan, 2018).

Badan penelitian kesehatan dunia WHO (2018), mengadakan tinjauan terhadap beberapa negara di dunia dan mendapatkan persentase dari angka kejadian gastritis di dunia, diantaranya Inggris 22\%, China 31\%, Jepang 14,5\%, Kanada 35\%, dan Perancis $29,5 \%$. Di dunia, kejadian gastritis 1,8-2,1 juta dari jumlah penduduk setiap tahun. Angka kejadian gastritis di Asia Tenggara sekitar 583.635 dari jumlah penduduk setiap tahunnya. Persentase angka kejadian gastritis di Indonesia didapatkan mencapai angka 40,8\% (Infodatin, 2016).

Penyakit Gastritis sering dialami oleh banyak orang. Penyakit Gastritis dialami dari usia dini hingga usia tua. Kejadian gastritis di Indonesia cukup tinggi. Berdasarkan hasil data dari Departemen Kesehatan RI, angka kejadian gastritis di beberapa kota di
Indonesia ada yang mencapai 91,6\% yaitu di kota Medan, lalu di beberapa kota lainnya seperti Surabaya 31,2\%, Denpasar 46\%, Jakarta 50\%, Bandung 32,5\%, Palembang 35\%, Aceh 31,7\%, dan Pontianak 31,2 \%. Hal tersebut disebabkan oleh pola makan yang kurang sehat (Rial, 2017).

Provinsi Kepulauan Riau, setiap tahunnya gastritis masuk kedalam kategori 10 penyakit terbesar, berdasarkan data dari Dinas Kesehatan Provinsi Riau penyakit gastritis pada tahun 2018 menduduki peringkat ketujuh dari sepuluh penyakit terbesar dengan jumlah sebesar 13.471 kasus (Dinkes Pekanbaru, 2018). Tahun 2019, penyakit Gastritis merupakan salah satu penyakit dalam sepuluh penyakit terbanyak di Kota Batam dan lebih banyak diderita oleh laki -laki dari pada perempuan dengan jumlah 2.104 kasus (Dinas Kesehatan Batam, 2019).

Tingginya angka kejadian gastritis dipengaruhi oleh beberapa faktor secara garis besar penyebab gastritis dibedakan atas zat internal yaitu adanya kondisi yang memicu pengeluaran asam lambung yang berlebihan, dan zat eksternal yang menyebabkan iritasi dan infeksi. Gastritis biasanya terjadi ketika mekanisme perlindungan dalam lambung mulai berkurang sehingga meninmbulkan peradangan (inflamasi). Penyebab dari kerusakan karena adanya gangguan kerja fungsi lambung, gangguan struktur anatomi yang bisa berupa luka atau tumor (Suryono, 2018). 
Vol.3.No 1 (2021)

p-ISSN :2657-2435

e-ISSSN:2721-3145

Dampak dari penyakit gastritis dapat menganggu aktivitas pasien seharihari karena munculnya berbagai keluhan seperti rasa sakit ulu hati, rasa terbakar, mual, muntah lemas, tidak nafsu makan dan keluhankeluhan lainnya (Wahyuni, Eko, Lestariningsih, \& Makan, 2017). Jika tidak segera ditangani dapat menimbulkan komplikasi seperti gangguan penyerapan vitamin B12, anemia pernesiosa, penyerapan besi terganggu, penyempitan daerah antrum pylorus. Dampak jangka panjang dapat menyebabkan tukak lambung, perdarahan hebat, dan kanker. Risiko terkena kanker lambung dapat menyebabkan kematian (Malda, 2018). Untuk itu harus ada penatalaksanaan yang harus dilakukan.

Penatalaksanaan gastritis yaitu dengan membantu meredakan nyeri dengan pendekatan farmakologis dan non farmakologis.Penanganan gastritis dengan farmakologi bisa dilakukan dengan pemberian obatobatan. Sedangkan dengan non farmakologi bisa melalui tanaman obat seperti daun andong, daun jambu biji, kulit kayu manis, kunyit, lidah buaya, pegagan, pisang batu, putri malu, temu lawak, dan pepaya. Masyarakat cenderung mengkonsumsi obat-obatan untuk meredakan nyeri, namun mengkonsumsi obat-obatan secara terus menerus dapat menimbulkan perubahan kualitatif mukus mengakibatkan kerusakan jaringan. Alternatif terapi herbal untuk meredakan nyeri bisa dengan mengaplikasikan Pemberian Jus
Buah Pepaya (Carica Papaya) Terhadap Nyeri Kronis Pada Keluarga Dengan Gastritis Anon dkk, (2018).

Dalam penelitian Anon dkk, (2018). Menunjukan pengaruh pemberian jus buah pepaya terhadap tingkat nyeri pada penderita gastritis. Dari penelitian tersebut buah pepaya memiliki kandungan mineral asam basa lemah yang dapat digunakan untuk menetralisir asam lambung, sehingga nyeri yang dirasakan akibat peningkatan asam lambung dapat berukurang.

Dalam penelitian Anon dkk, (2018). Buah pepaya mengandung nutrisi seperti betakaroren, vitamin $\mathrm{C}$, vitamin $\mathrm{B}$, mineral, serat, lycopene dan flavonoid, sehingga mempunyai fungsi sebagai zat antikanker. Konsumsi jus buah pepaya dilakukan sebanyak 4 hari dengan hari yang berbeda bisa menggunakan sebanyak 200 gram bahan segar untuk dihaluskan menjadi jus dan air 150 ml. untuk waktu yang tepat dalam mengkonsumsi jus buah pepaya antara pukul $12.00-20.00$.

Berdasarkan uraian diatas penulis mengambil kasus tersebut untuk menerapkan inovasi mengatasi tingkat nyeri pada gastritis dengan judul "asuhan keperawatan pada pasien gastritis dengan pemberian jus buah pepaya untuk menurunkan intensitas nyeri di wilayah Sei Panas Kota Batam.”.

\section{METODE PENELITIAN}

Metode yang digunakan dalam penelitian ini adalah studi kasus yang 
dilakukan berdasarkan tahap-tahap asuhan keperawatan meliputi pengkajian, diagnosa, intervensi, implementasi, dan evaluasi keperawatan. Penelitian ini dilakukan di wilayah sei. Panas. Pelaksanaannya dilakukan selama 5 hari mulai tanggal 01 September 2020 - 05 September 2020. Alat yang digunakan yaitu blender pembuat jus, dan adapun bahan yang digunakan yaitu buah papaya.

\section{HASIL DAN PEMBAHASAN}

Pada proses pengkajian penulis memperoleh data dengan menggunakan metode wawancara yang dilakukan secara langsung kepada klien. Selain itu juga penulis memperoleh data dari observasi langsung. Selama melakukan pengkajian penulis tidak banyak menemukan hambatan yang berarti dalam memperoleh data tentang klien. Hal ini dikarenakan adanya kerjasama dari klien ke penulis.

Dari hasil pengkajian didapatkan nyeri yang muncul dari penyakit gastritis yang dialami klien, sehingga menyebabkan nafsu makan menurun dan rasa mual, kemudian juga klien tampak gelisah dan cemas dengan penyakit yang dialaminya, dari hasil pengkajian yang didapatkan sebelum sakit pasien sering telat makan dan makan dalam porsi yang besar serta jenis makanan yang di konsumsinya adalah jenis makan berminyak, asam, pedas dan berbumbu, hal ini juga dapat memicu terjadinya peningkatan nyeri pada klien.

Hasil pengkajian diatas sesuai dengan teori yang sampaikan oleh
Maryam (2015) yaitu Penyebab nyeri pada pasien gastritis adalah penggunaan NSAID/OAINS atau medikasi lain yang mengiritasi lapisan lambung, seperti aspirin, konsumsi alkohol dalam jumlah banyak, penyakit refluks gastroesofagus, merokok, virus, menelan racun, atau stress akibat penyakit, pembedahan, atau hipertensi porta semuanya dapat menyebabkan kondisi ini. infeksi bakteri H. Pylori, terlambat makan, pola makan penyakit dan makanmakanan yang pedas.

Hasil pengkajian juga sesuai dengan penelitian yang dilakukan oleh (Aspiani 2016) dengan judul penelitian "Pengaruh Pemberian Jus Buah Pepaya (Carica Papaya) Terhadap Tingkat Nyeri Kronis Pada Penderita Gatritis di Wilayah Puskesmas Mungkid” yang mengungkapkan hasil pengkajian pasien dengan gastritis yaitu menunjukkan tanda dan gejala nyeri, gelisah serta cemas dan nafsu makan menurun serta mual dan muntah. Berdasarkan uraian diatas dapat di simpulkan bahwa terdapat kesamaan antara hasil pengkajian yang dilakukan, teori serta penelitian yang telah dilakukan sebelumnya.

Pada studi kasus penulis menemukan 3 (tiga) diagnosa keperawatan yaitu: Nyeri akut berhubungan dengan, inflamasi mukosa lambung, Ketidakseimbangan nutrisi kurang dari kebutuhan tubuh beerhubugan dengan anoreksia, dan Ansietas berhubungan dengan perubahan status kesehatan, ancaman nyeri. Hal ini sedikit berbeda dengan teori, 
menurut Lukman (2016) ada 4 diagnosa keperawatan yang mungkin muncul pada Gastritis yaitu Nyeri akut berhubungan dengan inflamasi mukosa lambung, Kekurangan volume cairan berhubungan dengan intake yang tidak adekuat (mual dan muntah), Ketidakseimbangan nutrisi kurang dari kebutuhan tubuh berhubungan dengan anoreksia dan Ansietas berhubungan dengan perubahan status kesehatan, ancaman nyeri

Sedangkan berdasarkan penelitian sebelumnya yang dilakukan oleh Rina (2017) dengan judul "Asuhan Keperawatan pada Ny.E dengan Prioritas Masalah Nyeri pada Gastritis Di Lingkungan V Sari Rejo Medan Polonia" terdapat kesamaan dengan studi kasus dimana pada penelitian sebelumnya juga mengangkat 3 masalah yaitu Nyeri berhubungan dengan inflamasi mukosa lambung ditandai dengan wajah dengan klien menggunakan alat skala nyeri, ketidakseimbangan nutrisi kurang dari kebutuhan tubuh berhubungan Anoreksia ditandai dengan mual dan muntah, Ansietas berhubungan dengan perubahan status kesehatan ancaman nyeri.

Menurut data yang diperoleh dari Depkes RI, (2018) mencatat 80\% orang dewasa yang mengalami gastritis disebabkan pola makan yang tidak teratur dan stres yang berlebihan menyebabkan pasien banyak mengalami nyeri pada bagian epigastrium. (Cintyawati, 2014).

Dari pendapat di atas dapat disimpulkan bahwa penyakit gastritis lebih besar perkiraannya mengalami rasa nyeri, hal ini sejalan dengan studi kasus yang dilakukan dimana pasien mengalami nyeri serta cemas yang menimbulkan nafsu makan menjadi menurun.

Pada perencanaan keperawatan terdiri dari prioritas diagnosa keperawatan dan rencana keperawatan. Untuk prioritas diagnosa keperawatan ditulis berdasarkan masalah utama . Dalam kasus ini, diagnosa keperawatan yang muncul adalah Nyeri akut berhubungan dengan imflamasi mukosa lambung. Penyusunan rencana keperawatan meliputi langkah - langkah menentukan tujuan yaitu tujuan umum yang mengacu pada masalah dan tujuan khusus yang mengacu pada penyebab, menentukan kriteria evaluasi, rencana, intervensi serta membuat rasional atas intervensi yang dilakukan (Damaiyanti, 2015).

Penyusunan intervensi keperawatan yang dilakukan oleh penulis berdasarkan diagnosa yang penulis temukan dan disesuaikan berdasarkan kebutuhan klien. Adapun intervensi utama yang dilakukan pada Tn. F yaitu untuk masalah nyeri dilakukan tindakan non farmakologi untuk mengurangi rasa nyeri yaitu dengan memberikan jus buah pepaya.

Buah pepaya memiliki dua mekanisme yang pertama pepaya mengandung mineral basa lemah yang berfungsi untuk menetralisir asam lambung sehingga nyeri dapat berkurang dan mekanisme yang kedua pepaya mempunyai 
Vol.3.No 1 (2021)

p-ISSN :2657-2435

e-ISSSN:2721-3145

kandungan enzim papain yang mampu mempercepat pemecahan protein didalam lambung karena pada saat terjadi gastritis enzim pepsin yang berperan dalam pemecahan protein mengalami penurunan. (Kanji, et al, 2018; Saunders, 2018).

Widyastuti (2014) menambahkan bahwa jus buah pepaya membantu individu untuk dapat mengendalikan beberapa fungsi tubuh seperti mengurangi rasa nyeri, masalah lambung dan pencernaan.

Intervensi yang dilakukan serta teori diatas juga didukung oleh penelitian yang dilakukan oleh Junila (2018) dengan judul penelitian "Pengaruh Pemberian Jus Buah Pepaya Terhadap Nyeri Pada Ny. G Dengan Gastritis Di Wilayah Kerja Puskesmas Andalas Padang Tahun 2018" dengan Hasil penelitian menunjukkan bahwa rata - rata skala nyeri sebelum diberikan jus buah pepaya adalah 5,19, dan rata - rata skala nyeri setelah di berikan jus buah pepaya adalah 3,23 yang menunjukkan bahwa pemberian jus buah pepaya dapat mengurangi skala nyeri pada Ny. G.

Pada masalah keperawatan Nyeri akut tindakan utama yang dilakukan berdasarkan salah satu Intervensi menurut NANDA (2014) adalah dengan memberikan jus buah pepaya untuk penurunan tingkat nyeri pada Gastritis. Jus buah pepaya mengandung nutrisi dan vitamin $\mathrm{C}, \mathrm{A}, \mathrm{K}$, folat, mineral, magnesium, tembaga, antioksidan, beta-karoten, lutein, kalsium,dan potasium yang dibutuhkan oleh tubuh umumnya mengonsumsi buah pepaya selain meredakan asam lambung dan juga memberikan nutrisi yang baik bagi tubuh. (Campbell et al, 1997).

Intervensi yang dilakukan serta teori diatas juga di dukung oleh penelitian yang dilakukan Mahendra (2016) dengan judul penelitian "Pengaruh Pemberian Jus Pepaya Terhadap Nenurunan Nyeri Akut Pada Pasien Di Puskesmas Tabanan" jus buah pepaya yang dapat mengurangi nyeri pada pasien gastritis.

Pelaksanaan tindakan keperawatan yang dilakukan oleh penulis secara nyata langsung kepada klien merupakan realisasi dari intervensi keperawatan yang sesuai dengan konsep teori yang dilaksanakan selama 4 hari secara bertahap, spesifik dan akurat. Namun pelaksanaannya dilakukan selama 5 hari mulai tanggal 01 September 2020 - 05 September 2020. Implementasi diagnosa untuk Nyeri Akut b.d inflamasi mukosa lambung dilakukan selama 5 hari dengan pemberian jus buah pepaya bisa mengurangi rasa nyeri ringan dan sedang.

Masalah keperawatan dapat diatasi dan dimandirikan kepada pasien selama 5 kali pertemuan dengan hasil klien mampu mengontrol rasa nyeri dengan memberikan jus buah pepaya, klien mengungkapkan nyeri berkurang dengan penurunan skala nyeri dari skala 5 menjadi 0 .

Berdasarken teori yang dikemukakan oleh Widiastuti (2015) 
Vol.3.No 1 (2021)

p-ISSN :2657-2435

e-ISSSN:2721-3145

pemberian jus buah pepaya satu hari sekali dapat memberikan hasil setelah dilakukan selama empat hari.

Berdasarkan oleh penelitian yang dilakukan oleh Junila (2018) dengan judul penelitian "Pengaruh Pemberian Jus Buah Pepaya Terhadap Nyeri Pada Ny. G Dengan Gastritis Di Wilayah Kerja Puskesmas Andalas Padang Tahun 2018" Jus buah pepaya diberikan satu hari sekali selama tujuh hari responden merasakan nyeri berkurang.

Jus buah pepaya mengandung nutrisi dan vitamin $\mathrm{C}, \mathrm{A}, \mathrm{K}$, folat, mineral, magnesium, tembaga, antioksidan, beta-karoten, lutein, kalsium,dan potasium yang dibutuhkan oleh tubuh umumnya mengonsumsi buah pepaya selain meredakan asam lambung juga memberikan nutrisi yang baik bagi tubuh klien. (Campbell etal, 1997).

\section{KESIMPULAN}

Setelah dilakukan asuhan keperawatan pada klien gastritis dengan terapi non farmakologi dengan pemberian jus buah pepaya selama 5 hari berturtut-turut, dapat terjadi penurunan Tingkat nyeri dari skala 5 menjadi skala 0 setelah dilakukan tindakan Dapat disimpulkan bahwa jus buah pepaya dapat menurunkan skala nyeri pada pasien gastritis.

\section{UCAPAN TERIMAKASIH}

Alhamdulillah Puji syukur kehadirat Allah SWT, yang telah melimpahkan rahmat dan ridho-Nya sehingga penulis dapat menyelesaikan laporan penelitian ini.
Penyelesaian Penelitian ini penulis banyak mendapatkan bantuan, bimbingan, saran, keterangan dan data-data baik secara tertulis maupun secara lisan. Maka pada kesempatan ini juga penulis ingin menyampaikan ucapan terima kasih kepada:

1. Bapak H. Henry Minit, selaku Ketua Umum Yayasan Harapan Bunda Batam.

2. Ibu $\mathrm{Hj}$ Gusnawati Amd.Keb, selaku Ketua Yayasan Institut Kesehatan Mitra Bunda Batam

3. Bapak Dr. H. Mawardi Badar, MM selaku Rektor Institut Kesehatan Mitra Bunda Batam

4. Kepala Dinas Kesehatan Kota Batam beserta seluruh staf yang telah memberikan sumber informasi data.

5. Kepala Puskesmas dan seluruh pegawai Puskesmas Sei. Panas yang telah memberi izin tempat penelitian dan telah banyak membantu. .

\section{REFERENSI}

Anon dkk. 2018. Mengenal Penyakit Organ Cerna: Gastritis (Dyspepsia atau Bedah. Jakarta: Salemba Medika.

Budiyanto. 2016. Konsep Dasar Keperawatan. Jakarta: EGC

Dinkes Pekanbaru. profil kesehatan Pekanbaru Riau tahun 2018

Fadhilah. 2016. Konsep Dasar Keperawatan. Jakarta: EGC

Gustin. 2017. Gangguan Gastrointestinal Aplikasi Asuhan Keperawatan Medikal Bedah. Jakarta: Salemba Medika. 
Vol.3.No 1 (2021)

p-ISSN :2657-2435

e-ISSSN:2721-3145

Indayani. 2018. Rencana Asuhan Keperawatan. Jakarta: EGC

Khoirul Amin dkk. 2017. Ilmu Penyakit Dalam. Jakrta: Rineka Cipta

Kunuria. 2018 Buku Ajar Keperawatan Medikal-Bedah. Jakarta: EGC

Lescher, 2017 "Pengaruh lep wrapping di RSud Muntilan".Jurnal. maag), Infeksi Mycobacteria pada Ulser Gastrointestinal. Jakarta: Pustaka Populer Obor.

Malda. 2018. Departemen Ilmu Penyakit Dalam FKUI

Mansjoer dkk. 2017. Diagnosa Keperawatan : Diagnosis NANDA Intervensi NIC

Nanda. 2018. Buku Ajar Ilmu Penyakit Dalam. Jakarta: Pusat Penerbitan Departemen

Rial. 2017. Profil Kesehatan Indonesia, Kansius Jakarta.

Sibuea, Herdin dkk 2018. Ilmu Penyakit Dalam. Jakarta: Rineka Cipta

Smeltzer, 2018 . Proses Keperawatan: Teori dan Aplikasi. Yogyakarta: AR RUZZ MEDIA

Sukarmin. 2016. Patofisiologi: Konsep Klinis Proses-Proses Penyakit, Edisi 6.Jakarta:EGC
Sherwood, 2017Keperawatan Medikal Bedah Sistem Pencernaan. Yogyakarta :Gosyen Publising.

Suratun. 2018. Mengenal Penyakit Organ Cerna: Gastritis (Dyspepsia atau (maag), Infeksi Mycobacteria pada Ulser Gastrointestinal. Jakarta: Pustaka Populer Obor.

Suryono, 2018. Ilmu Penyakit Dalam. Jakarta :Rineka Cipta 